\title{
PENGARUH SUHU TERHADAP PENAMBAHAN BAKTERI Eschericia coli O157:H7 DALAM URIN UNTUK PEMBENTUKAN BIOFILM DAN PRODUKSI ELEKTRON
}

\author{
Oleh : \\ Ahmad Riza $W^{1}$, Avin Ainur $\mathbf{F}^{2}$
}

\begin{abstract}
ABSTRAK: Kebutuhan energi listrik di Indonesia yang terus meningkat telah memicu dilakukannya berbagai riset ke arah teknologi inovatif yang lebih efektif, efisien dan ramah lingkungan untuk memproduksi energi listrik. Salah satu teknologi alternatif yang bisa dikembangkan adalah Microbial Fuel Cell (MFC) yang berbasis prinsip bioelektrokimia dengan memanfaatkan urin dan mikroorganisme bakteri Eschericia Coli untuk memecah substrat sehingga menghasilkan energi listrik.

Tujuan penelitian ini adalah untuk mengukur efisiensi Urin dan bakteri Eschericia Coli dalam menghasilkan elektron dan mengetahui pembentukan biofilm yang terjadi, Metode penelitian yang digunakan adalah studi eksperimental dengan melakukan uji perbandingan hasil Kuat Arus dan Tegangan pada perlakuan variasi temperatur dan nilai Optical Density yang dihasilkan, serta Daya Hantar Listrik.

Hasil yang diperoleh dari penelitian ini yaitu pada od 0 dengan nilai Imax 1,815 A dan Vmax 0,849 V pada suhu $37^{\circ} \mathrm{C}$, dan nilai Power Density 559,125 mW .Pada beberapa nilai OD dan perlakuan variasi temperatur di dapat nilai kuat arus dan Tegangan mengalami kenaikan ini bisa terjadi karena bakteri E.coli yang digunakan sedang berada pada fase eksponensial. Ada juga nilai kuat arus dan tegangan mengalami penurunan, Penurunan ini terjadi sehubungan dengan kondisi bakteri yang mulai memasuki fase kematian. dan penurunan kuat arus dan tegangan juga bisa terjadi sehubungan dengan aktivitas bakteri di dalam anoda yang lama kelamaan dapat membentuk Biofilm pada permukaan elektroda dan semakin tinggi konsentrasi suatu larutan semakin tinggi daya hantar listriknya atau konduktivitasnya.
\end{abstract}

Kata Kunci: energi alternatif, microbial fuel cell (mfc), urin, bakteri eschericia coli O157:H7

\begin{abstract}
Requirement of electrics energy in Indonesia which increasing have triggered of various research into up at inovative technology which more effective, efficient, and friendly of environment to produce electrics energy. One of them which can developed is Microbial Fuel Cell (MFC) which base on principle of bioelectrics and chemistry by exploiting of urine and the bacterium of Eschericia coli $\mathrm{O} 157: \mathrm{H} 7$ to break substract so that produce the electrics energy.

The purpose of this research is for measuring of urine efficient and bacterium of Eschericia coli O157:H7 in producing electron and knowing of forming biofilm that happened. The used research methode is experiment studying which doing the test comparison of strong result of current and tension at treatment of temperature variation and value of Optical Density (OD) that produced, and the energy pass electrics.

The result from this research is on OD 0 with value of $I_{\max } 1,815 \mathrm{~A}$ and $\mathrm{V}_{\max } 0,849 \mathrm{~V}$ on temperature $37^{\circ} \mathrm{C}$ and on power density $559,125 \mathrm{~mW}$. In some the value of OD and treatment of temperature variation obtained by strong value of current and tension have increasing, because Eschericia coli O157:H7 which used is residing in phase of exponential. There are value of current and tension have degradation, because the condition of bacterium starting phase of death. And degradation current and tension also can happened because the relation of bacterium activity in anode for long time can form the biofilm on surface of electrode and if the concentration of fluide go to high, so the energy pass electrics go to high too or its conductivity.
\end{abstract}

Keywords: Alternative Energy, Microbial Fuel Cell (MFC), Urine, Bacterium Of Eschericia coli O157:H7

1,2 Jurusan Fisika Universitas Islam Negeri (UIN) Maulana Malik Ibrahim Malang el.wahdy @gmail.com 


\section{PENDAHULUAN}

Saat ini di lingkungan sekitar telah mengalami suatu problematika yang sangat penting. Sumber energi utama berupa bahan bakar yang banyak didapatkan dari kekayaan alam kini mulai punah. Hal ini disebabkan karena kebutuhan masyarakat akan sumber energi semakin meningkat sedangkan alat pemenuh kebutuhannya yang berupa bahan bakar terbatas jumlahnya. Serta membutuhkan waktu yang lama untuk proses produksinya kembali, atau bahkan sudah tidak bisa diperbaharui lagi.

Penelitian ini merupakan penelitian eksperimental bersakala laboratorium yang bertujuan untuk mengetahui pembentukan biofilm yang terjadi dari bakteri Eschericia coli O157:H7 di dalam urin, serta mengukur hasil elektron (kuat arus, tegangan, power density dan daya hantar listrik) sebelum dan sesudah adanya perlakuan penambahan bakteri menggunakan metode optical density (OD), Untuk pengukuran elektron menggunaakan reaktor Microbial Fuel Cell (MFC) single chamber.

Urin atau air seni atau air kencing adalah cairan sisa yang diekskresikan oleh ginjal yang kemudian akan dikeluarkan dari dalam tubuh melalui proses urinasi. Ekskreksi urin diperlukan untuk membuang molekul-molekul sisa dalam darah yang disaring oleh ginjal dan untuk menjaga homeostasis cairan tubuh. Peranan urin sangat penting untuk mempertahankan homeostasis tubuh, karena sebagian pembuangan cairan oleh tubuh adalah melalui sekresi urin [4].

Escherichia coli termasuk dalam family Enterobacteraceae yang termasuk gram negatif dan berbentuk batang yang fermentatif. E. coli hidup dalam jumlah besar di dalam usus manusia, yaitu membantu sistem pencernaan manusia dan melindunginya dari bakteri patogen. Akan tetapi pada strain baru dari E.coli merupakan patogen berbahaya yang menyebabkan penyakit diare dan sindrom diare lanjutan serta hemolitik uremic (hus). Peranan yang mengguntungkan adalah dapat dijadikan percobaan limbah di air, indikator pada level pencemaran air serta mendeteksi patogen pada feses manusia yang disebabkan oleh Salmonella typhi [2].

Biofilm adalah lapisan yang merupakan koloni dari konsorsium mikroba yang menempel dan menutupi suatu permukaan benda padat di lingkungan berair. Para ahli mikrobiologi memperkirakan bahwa biofilm adalah cara hidup mikroorganisme yang dominan dibandingkan dengan cara hidup melayang-layang di dalam cairan atau planktonis. Biofilm merupakan sebuah struktur komunitas dari bakteri, algae atau jenis sel lainnya yang menghasilkan matriks polimerik dan melekat pada permukaan. Bakteri kebanyakan hidup sesil (pada suatu permukaan), membentuk komunitas kehidupan jika memungkinkan, yang dapat memberikan keuntungan lebih dibanding hidup secara planktonik. Secara fisik, keberadaan biofilm dapat dicirikan sebagai berikut [6].

Fuel cell merupakan teknologi elektrokimia yang secara kontinyu mengkonversi energi kimia menjadi energi listrik selama terdapat bahan bakar dan pengoksidan, Dalam fuel cell reaksi oksidasi terjadi pada anoda dan reaksi reduksi terjadi pada katoda. Reaksi oksidasi menghasilkan elektron yang dialirkan menuju katoda melalui sirkuit eksternal. Sirkuit menjadi sempurna dengan adaya pergerakan ion positif melalui elektrolit menuju ruang katoda [1]. 


\section{Preparasi Sampel Urine}

Adapun preparasi yang dilakukan pada tahap ini adalah disiapkan sampel urine manusia dewasa dengan volume $500 \mathrm{~mL}$ dari dalam kondisi sehat, Sampel urine diaduk dengan magnetik stirrer selama 30 menit dan dipindahkan urine ke dalam beaker glass.

\section{Preparasi Elektroda Perak}

Disiapkan dua elektroda tembaga dan seng dengan ukuran $4 \mathrm{~cm} \times 6 \mathrm{~cm}$, kemudian direndam dalam $\mathrm{HCl} 1 \mathrm{M}$ selama 1 hari, kemudin direndam dalam $\mathrm{NaOH} 1 \mathrm{M}$ selama 1 hari, setelah itu Elektroda dibilas dan direndam dalam aquades hingga saat akan digunakan.

\section{Preparasi Bakteri}

Adapun langkah penelitian dalam preparasi bakteri Eschericia Coli non patogenik adalah 1 isolat bakteri dimana bakteri jenis ini adalah bakteri non patogenik Ditumbuhkan pada media Eosin Methylen Blue, dan diinkubasi pada suhu $37^{\circ} \mathrm{C}$ selama 24 jam. Kemudian didapatkan koloni tunggal yang berwarna hijau kilap logam ditumbuhkan pada media Luria Agar (LA) dan diinkubasi selama 12 jam pada suhu $37^{\circ} \mathrm{C}$. Setelah itu di biakan disimpan dalam suhu $4^{0} \mathrm{C}$.

\section{Pengukuran Daya Hantar Listrik meunggunakan Konduktivity Meter}

Disiapkan alat Baker glass, Dipindahkan urine $500 \mathrm{~mL}$ pada baker glass dan di masukan ke MFC $50 \mathrm{~mL}$, Kemudian diukur arus dan tegangan optimum mulai tanpa penambahan bakteri atau $\mathrm{OD}=0 ; \mathrm{OD}=0,2 ; \mathrm{OD}=0,4 ; \mathrm{OD}=0,6 ; \mathrm{OD}=0,8 ;$ dan $\mathrm{OD}=1$ Pengukuran untuk masing masing optical density adalah 1 jam untuk masing-masing variasi temperatur, Setelah didapat nilai daya hantar Listrik yang dihasilkan pada urine, Dari data yang sudah ada, kemudian dianalisis dengan metode statistik Uji Beda nyata, Untuk masing-masing data hasil pengamatan dicatat pada tabel hasil pengamatan.

\section{Pembentukan Biofilm dalam Urine}

Sampel Urin di tuang ke dalam MFC ukuran $50 \mathrm{~mL}$, lalu anoda dan katoda di masukan ke dalam urin sbagai media pertumbuhan biofilm, kemudian di masukan bakteri ke dalam urin dan di berikan variasi Temperatur, setelah itu di lihat pada Mikroskop Komputer untuk melihat pembentukan biofilm yang terjadi.

\section{HASIL DAN PEMBAHASAN}

\section{Desain Reaktor Mikrobial Fuel Cell (single chamber)}

Alat pada penelitian ini menggunakan reaktor Reaktor Mikrobial Fuel Cell (Single Chamber), Fuel cell adalah merupakan teknologi elektrokimia yang secara kontinyu mengkonversi energi kimia menjadi energi listrik selama terdapat bahan bakar dan pengoksidan. 

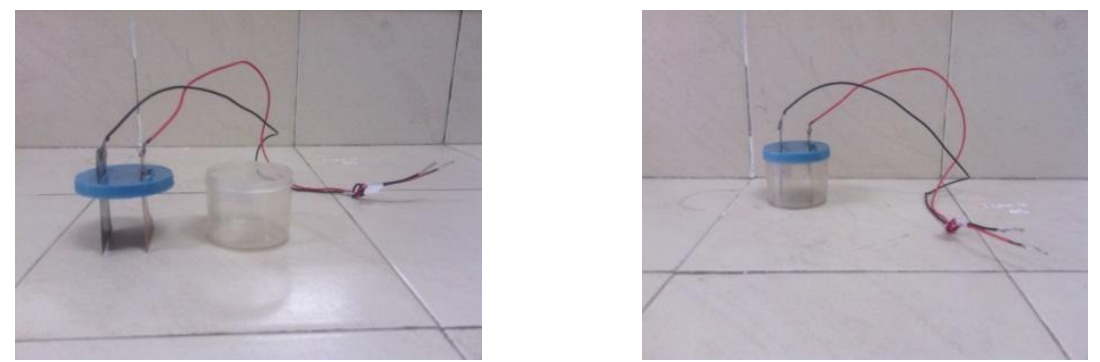

Gambar 1. Desain MFC (single Chamber) $50 \mathrm{~mL}$

Dalam fuel cell, reaksi oksidasi terjadi pada anoda dan reaksi reduksi terjadi pada katoda. Reaksi oksidasi menghasilkan elektron yang dialirkan menuju katoda melalui sirkuit eksternal, Elektroda yang digunakan pada setiap kompartemen adalah Lempeng Tembaga dan Lempeng Seng berukuran A. Luas permukaan elektroda ini sebesar 4x6 cm. Sebelum digunakan dalam sistem MFC, elektroda ini terlebih dahulu di rendam dalam $\mathrm{HCl}$ $1 \mathrm{M}$ dan $\mathrm{NaOH} 1 \mathrm{M}$. Kemudian elektroda disimpan di dalam aquades sampai akan digunakan. Hal ini bertujuan untuk meregenerasi elektroda dan menghilangkan kontaminasi logam dan bahan organik.

\section{Reaksi Kimia di Kompartemen Katoda dan Kompartemen Anoda}

Kompartemen anoda MFC diisi dengan urin yang mengandung molekul biodegradabel dan mikroba. Mikroba yang terdapat dalam Urin tersebut kemudian akan mengoksidasi molekul biodegradabel menghasilkan elektron, proton dan $\mathrm{CO} 2$. Proton menuju ke katoda melalui larutan elektrolit sedangkan elektron akan menempel ke anoda, kemudian mengalir melalui sirkuit listrik ke katoda. Aliran elektron inilah yang menghasilkan daya listrik. Pada katoda elektron, proton dan oksigen bergabung membentuk H2O. Secara umum reaksinya dapat dituliskan dalam Persamaan

$$
\text { Anoda }=\text { molekul biodegradabel }+\mathrm{H}_{2} \mathrm{O} \stackrel{\text { mikroba }}{\longrightarrow} \mathrm{CO}_{2}+e^{-}+\mathrm{H}^{+}
$$

Katoda $=\mathrm{O}_{2}+e^{-}+\mathrm{H}^{+} \stackrel{\text { mikroba }}{\longrightarrow} \mathrm{H}_{2} \mathrm{O}$

\section{Pengukuran Energi Listrik pada Variasi Optical Density (OD)}

Pada sistem MFC diperoleh data berupa tegangan dan arus. Proses pengukuran nilai tegangan dilakukan sesaat setelah pemasangan atau disebut pengukuran open circuits voltage (Voc). Pengukuran faktor yang mempengaruhi sebuah MFC dalam memproduksi energi. Pengukuran tegangan open circuits dilakukan sampai sistem mengalami kondisi steady state (kondisi tetap).

Tabel 1. Data dan Hasil pengukuran elektron secara fisika

\begin{tabular}{cccc}
\hline \multirow{2}{*}{ Suhu } & \multicolumn{2}{c}{ OD $=0$} & Power Density \\
\cline { 2 - 3 } & $\begin{array}{c}\text { Kuat Arus } \\
(\mathrm{mA})\end{array}$ & $\begin{array}{c}\text { Tegangan } \\
(\mathrm{V})\end{array}$ & \begin{tabular}{c}
$\left(\mathrm{mW} / \mathrm{m}^{2}\right)$ \\
\hline $25^{\circ} \mathrm{c}$
\end{tabular} \\
$28^{\circ} \mathrm{c}$ & 1,195 & 0,697 & 347,0479 \\
$31^{\circ} \mathrm{c}$ & 1,314 & 0,682 & 373,395 \\
$34^{\circ} \mathrm{c}$ & 1,512 & 0,742 & 467,46 \\
$37^{\circ} \mathrm{c}$ & 1,775 & 0,756 & 559,125 \\
\hline
\end{tabular}


Tabel 2. Data dan Hasil pengukuran elektron secara fisika

\begin{tabular}{cccc}
\hline \multirow{2}{*}{ Suhu } & \multicolumn{2}{c}{ OD=0,2 } & \\
\cline { 2 - 3 } & $\begin{array}{c}\text { Kuat Arus } \\
(\mathrm{mA})\end{array}$ & $\begin{array}{c}\text { Tegangan } \\
(\mathrm{V})\end{array}$ & Power Density $\left(\mathrm{mW} / \mathrm{m}^{2}\right)$ \\
\hline $25^{\circ} \mathrm{C}$ & 0,683 & 0,725 & 206,3229 \\
$28^{\circ} \mathrm{C}$ & 0,811 & 0,648 & 218,97 \\
$31^{\circ} \mathrm{C}$ & 0,831 & 0,671 & 232,3338 \\
$34^{\circ} \mathrm{C}$ & 0,935 & 0,787 & 306,6021 \\
$37^{\circ} \mathrm{C}$ & 1,228 & 0,849 & 434,405 \\
\hline
\end{tabular}

Tabel 3. Data dan Hasil pengukuran elektron secara fisika

\begin{tabular}{cccc}
\hline \multirow{2}{*}{ Suhu } & \multicolumn{2}{c}{ OD $=0,4$} & \\
\cline { 2 - 3 } & $\begin{array}{c}\text { Kuat Arus } \\
(\mathrm{mA})\end{array}$ & $\begin{array}{c}\text { Tegangan } \\
(\mathrm{V})\end{array}$ & Power Density $\left(\mathrm{mW} / \mathrm{m}^{2}\right)$ \\
\hline $25^{\circ} \mathrm{C}$ & 1,371 & 0,599 & 342,1788 \\
$28^{\circ} \mathrm{C}$ & 1,152 & 0,681 & 326,88 \\
$31^{\circ} \mathrm{C}$ & 1,304 & 0,752 & 408,586 \\
$34^{\circ} \mathrm{C}$ & 1,365 & 0,774 & 440,2212 \\
$37^{\circ} \mathrm{C}$ & 1,542 & 0,611 & 329,5675 \\
\hline
\end{tabular}

Tabel 4. Data dan Hasil pengukuran elektron secara fisika

\begin{tabular}{cccc}
\hline \multirow{2}{*}{ Suhu } & \multicolumn{2}{c}{ OD $=0,6$} & \\
\cline { 2 - 3 } & $\begin{array}{c}\text { Kuat Arus } \\
(\mathrm{mA})\end{array}$ & $\begin{array}{c}\text { Tegangan } \\
(\mathrm{V})\end{array}$ & Power Density $\left(\mathrm{mW} / \mathrm{m}^{2}\right)$ \\
\hline $25^{\circ} \mathrm{C}$ & 0,728 & 0,586 & 177,753 \\
$28^{\circ} \mathrm{C}$ & 0,835 & 0,608 & 211,533 \\
$31^{\circ} \mathrm{C}$ & 0,857 & 0,621 & 221,7488 \\
$34^{\circ} \mathrm{C}$ & 0,856 & 0,651 & 232,191 \\
$37^{\circ} \mathrm{C}$ & 1,261 & 0,735 & 386,1813 \\
\hline
\end{tabular}

Tabel 5. Data dan Hasil pengukuran elektron secara fisika

\begin{tabular}{cccc}
\hline \multirow{2}{*}{ Suhu } & \multicolumn{2}{c}{ OD $=0,8$} & \\
\cline { 2 - 3 } & $\begin{array}{c}\text { Kuat Arus } \\
(\mathrm{MA})\end{array}$ & $\begin{array}{c}\text { Tegangan } \\
(\mathrm{V})\end{array}$ & Power Density $\left(\mathrm{mW} / \mathrm{m}^{2}\right)$ \\
\hline $25^{\circ} \mathrm{c}$ & 0,469 & 0,742 & 144,9992 \\
$28^{\circ} \mathrm{C}$ & 0,829 & 0,751 & 259,4079 \\
$31^{\circ} \mathrm{C}$ & 0,797 & 0,761 & 252,7154 \\
$34^{\circ} \mathrm{C}$ & 0,838 & 0,775 & 270,604 \\
$37^{\circ} \mathrm{C}$ & 0,754 & 0,573 & 180,0175 \\
\hline
\end{tabular}


Tabel 6. Data dan Hasil pengukuran elektron secara fisika

\begin{tabular}{cccc}
\hline \multirow{2}{*}{ Suhu } & \multicolumn{2}{c}{ OD=1 } & \\
\cline { 2 - 3 } & $\begin{array}{c}\text { Kuat Arus } \\
(\mathrm{mA})\end{array}$ & $\begin{array}{c}\text { Tegangan } \\
(\mathrm{V})\end{array}$ & Power Density $\left(\mathrm{mW} / \mathrm{m}^{2}\right)$ \\
\hline $25^{\circ} \mathrm{c}$ & 0,688 & 0,483 & 138,461 \\
$28^{\circ} \mathrm{c}$ & 1,415 & 0,626 & 369,0792 \\
$31^{\circ} \mathrm{c}$ & 1,495 & 0,562 & 350,0792 \\
$34^{\circ} \mathrm{c}$ & 1,665 & 0,581 & 403,0688 \\
$37^{\circ} \mathrm{c}$ & 1,481 & 0,768 & 473,921 \\
\hline
\end{tabular}

Dari hasil ini dapat di lihat tabel di atas bahwa perlakuan variasi OD dan pengaruh suhu yang terjadi, di tiap perlakuan ternyata berpengaruh terhadap hasil kuat arus dan tegangan yang di hasilkan suatu sampel (Urin), contoh pada data OD 0 kuat arus dan tegangan mengalami kecenderungan naik tiap suhu. Pada beberapa nilai OD dan perlakuan suhu di dapat nilai kuat arus, Tegangan dan Power Density cenderung mengalami kenaikan ini bisa terjadi karena bakteri E.coli yang digunakan sedang berada pada fase eksponensial. Namun ada juga di beberapa suhu nilai kuat arus, Tegangan dan Power Density cenderung mengalami penurunan, Penurunan ini terjadi sehubungan dengan kondisi bakteri yang mulai memasuki fase kematian.

Dengan menggunakan persamaan Power Density $\left(\mathrm{mW} / \mathrm{m}^{2}\right)=\frac{I(\mathrm{~mA}) \times V \text { (volt) }}{A\left(\mathrm{~m}^{2}\right)}$

diperoleh hasil bahwa nilai power density maksimum sebesar 559,125 $\mathrm{mW} / \mathrm{m}^{2}$ dicapai pada saat OD 0 dan temperatur $34^{\circ} \mathrm{C}$. Ini berarti bahwa penambahan OD untuk nilai Power Density semakin banyak jumlah OD maka nilai Power Density cenderung mengalami penurunan.

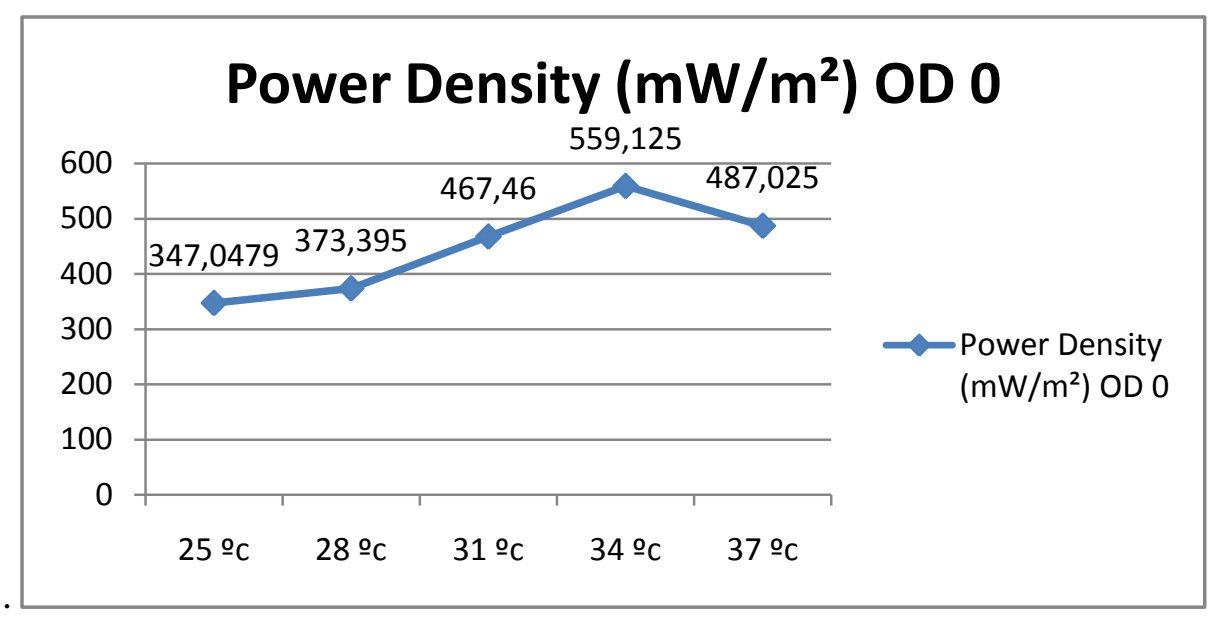

Gambar 2. Grafik Perbandingan Power Density Pada OD 0

dan Perlakuan Suhu 


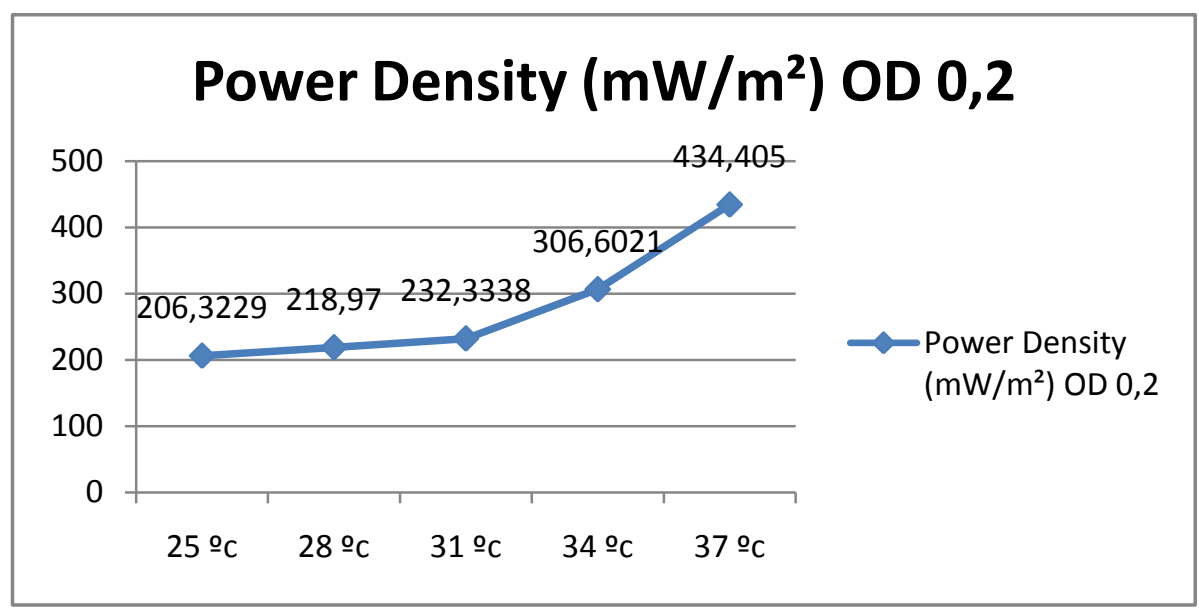

Gambar 3. Grafik Perbandingan Power Density Pada OD 0,2 dan Perlakuan Suhu

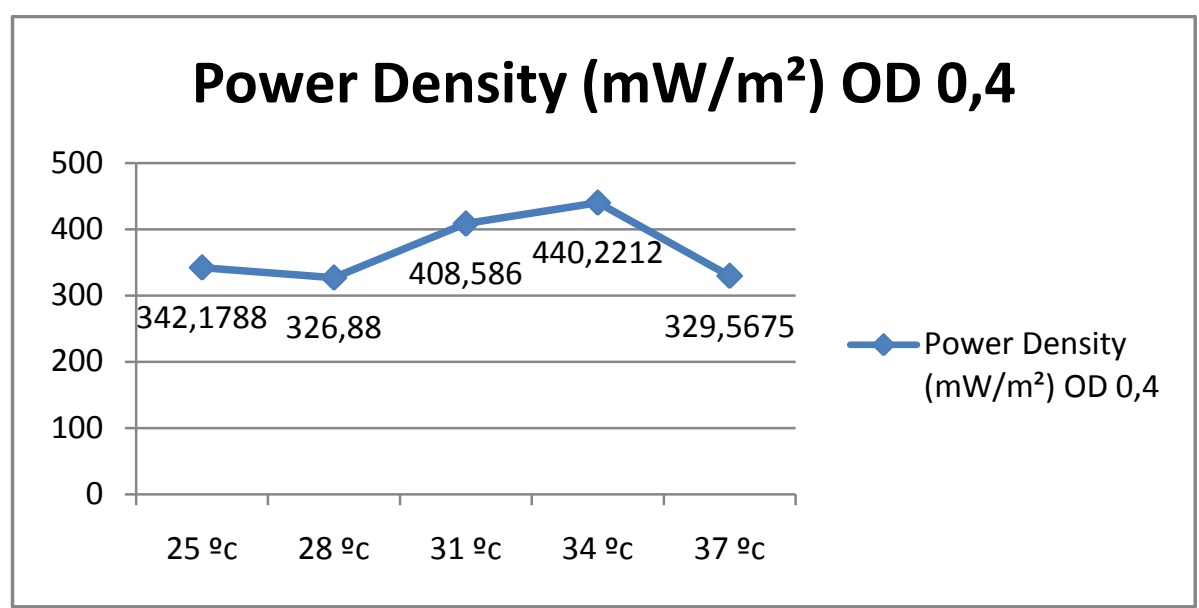

Gambar 4. Grafik Perbandingan Power Density Pada OD 0,4 dan Perlakuan Suhu

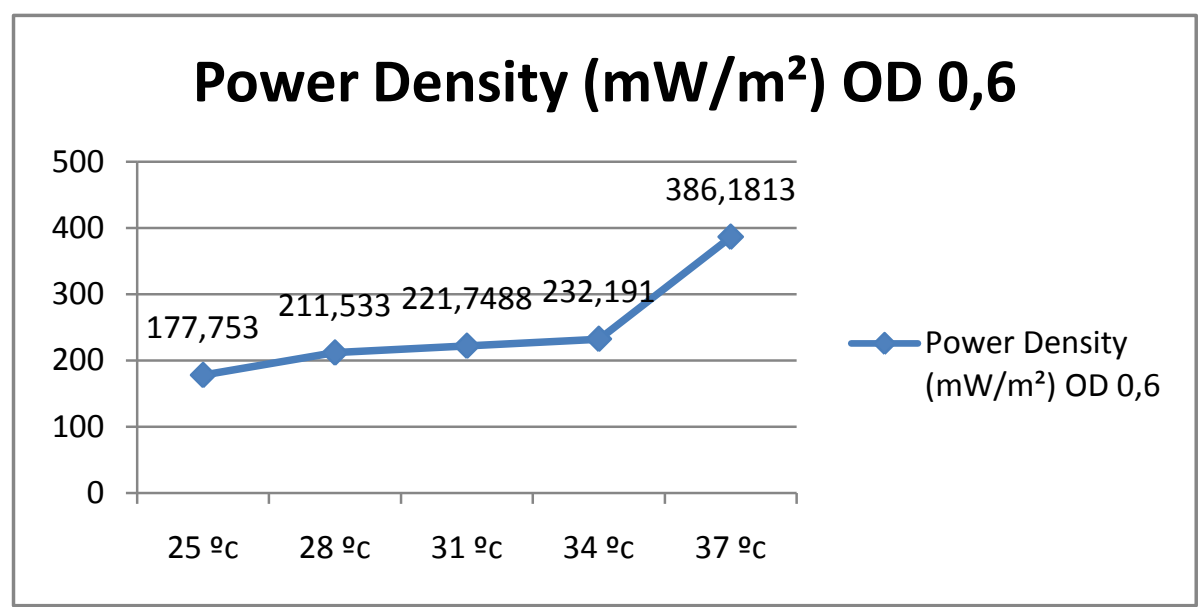

Gambar 5. Grafik Perbandingan Power Density Pada OD 0,6 dan Perlakuan Suhu 


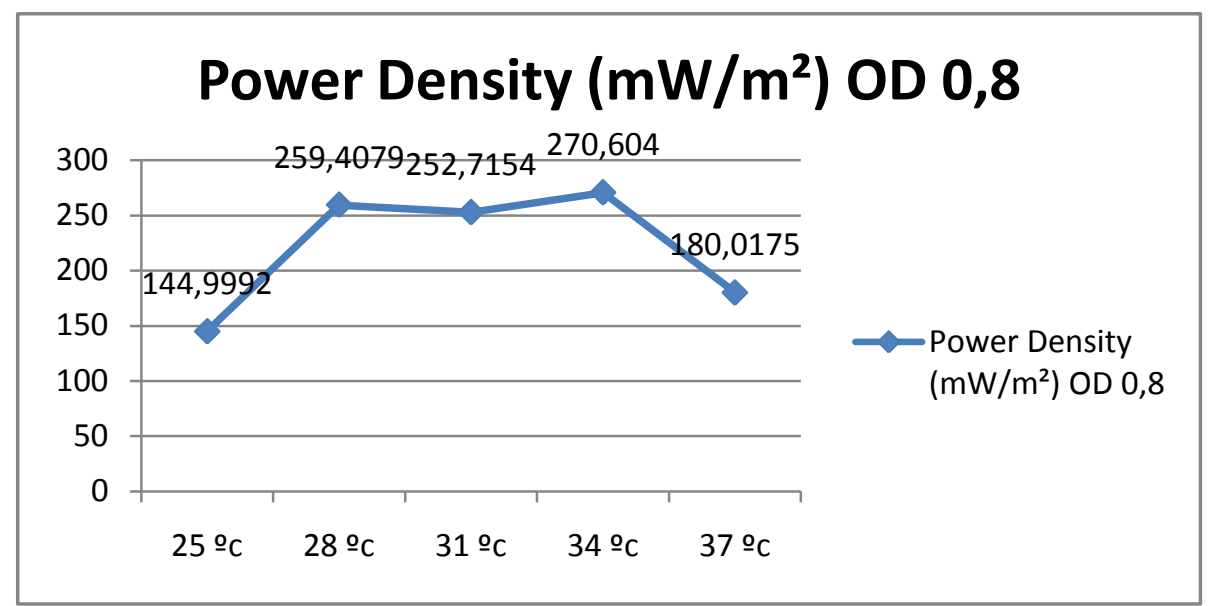

Gambar 6. Grafik Perbandingan Power Density Pada OD 0,8 dan Perlakuan Suhu

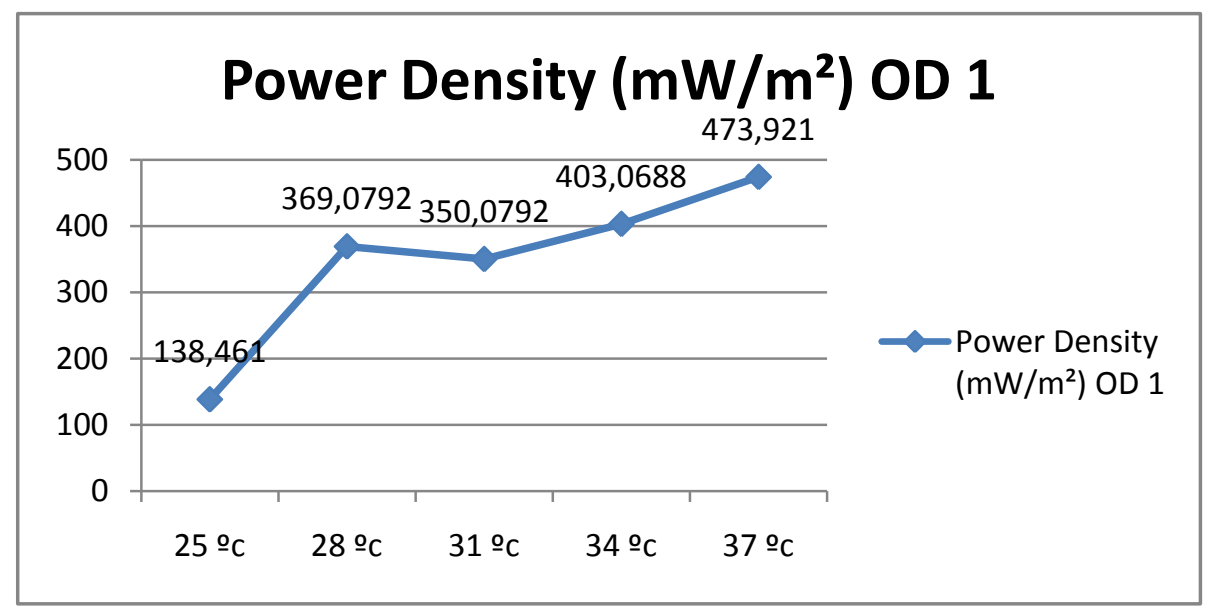

Gambar 7. Grafik Perbandingan Power Density Pada OD 1 dan Perlakuan Suhu

Tabel 7. Hasil Pengukuran Optical Density

\begin{tabular}{ccc}
\hline \multirow{2}{*}{ Sampel Urin } & Sebelum & OD \\
& Blank / & 0 \\
2 & 0,2 & 0,157 \\
3 & 0,4 & 0,335 \\
4 & 0,6 & 0,385 \\
5 & 0,8 & 0,464 \\
6 & 1 & 0,313 \\
\hline
\end{tabular}

Nilai OD dapat digunakan untuk merepresentasikan jumlah sel bakteri yang terdapat di ruang anoda. Apabila nilai OD semakin besar maka semakin banyak jumlah sel bakteri didalam reaktor. Bertambahnya jumlah sel bakteri ini memungkinkan semakin banyaknya proton dan elektron yang dapat dihasilkan dari proses metabolisme sehingga kuat arus yang terbaca semakin besar. Akan tetapi, jumlah glukosa sebagai substrat di anoda bernilai tetap. Akibatnya, terjadi perebutan "makanan" di antara sel bakteri sehingga tidak semua sel bakteri dapat melakukan metabolisme. Dan itu mempengaruhi hasil nilai OD sesudah 
perlakuan yang megalami penurunan dan kemngkinan di akibatkan oleh adanya perlakuan variasi temperatur yang membuat bakteri pada fase kematian. Oleh karena itulah penambahan nilai OD justru dapat menurunkan kuat arus yang dihasilkan.

\section{Pembentukan Biofilm yang terjadi dari bakteri Eschericia coli di dalam Urin menggunakan mikroskop komputer.}
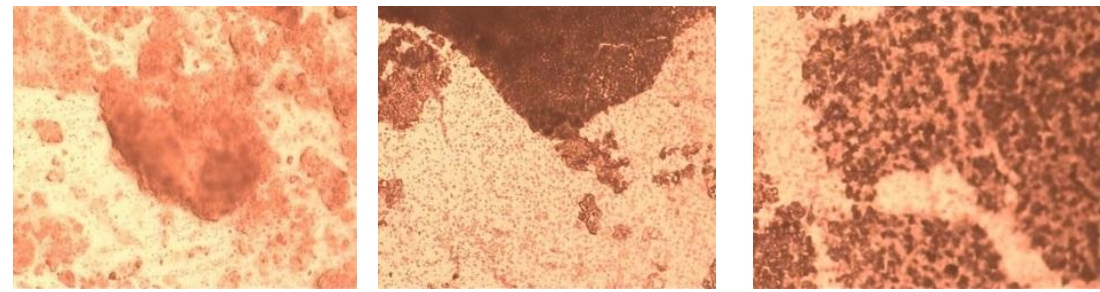

Gambar 8. pembentukan biofilm menggunakan Mikroskop Komputer

Dari gambar di atas menunjukkan elektroda anoda yang telah dilapisi oleh Biofilm setelah pemakaian 3 hari, Gambar di atas kemungkinan penampakan biofilm yang paling dominan terjadi pada OD 0,6 sehingga terlihat perkumpulan koloni bakteri E.coli, dalam penglihatan mikroskop banyak yang bergerak.

Sehubungan dengan aktivitas bakteri di dalam anoda yang lama kelamaan dapat membentuk Biofilm pada permukaan elektroda [3]. Terbentuknya Biofilm ini dapat mengakibatkan peningkatan hambatan dalam di anoda [5], dan dapat menyebabkan penurunan nilai Power Density [3]. Efisiensi transfer elektron dari bakteri ke elektroda sebanding dengan jumlah bakteri yang melakukan kontak dengan elektroda tersebut [5]. Apabila permukaan elektroda ini sudah dipenuhi oleh Biofilm, jumlah elektron yang dapat ditransfer ke elektroda akan sedikit sehingga terjadi penurunan energi listrik.

\section{KESIMPULAN}

Desain Reaktor pada penelitian ini menggunakan reaktor Reaktor Mikrobial Fuel cell (single chamber), Bakteri Eschericia Coli O157:H7 memiliki potensi sebagai penghasil listrik dalam sistem Microbial Fuel Cell (single Chamber) dan membentuk Biofilm, namun ada beberapa faktor yang dapat mempengaruhi produksi energi listrik yaitu bakteri, waktu operasi MFC, volume reaktor, dan jenis larutan elektrolit.

Pada beberapa nilai OD dan perlakuan temperatur di dapat nilai kuat arus, Tegangan dan Power Density cenderung mengalami kenaikan ini bisa terjadi karena bakteri E.coli yang digunakan sedang berada pada fase eksponensial. Namun ada juga di beberapa suhu nilai kuat arus dan tegangan cenderung mengalami penurunan, Penurunan ini terjadi sehubungan dengan kondisi bakteri yang mulai memasuki fase kematian.

Kecenderungan penurunan kuat arus dan tegangan terjadi sehubungan dengan aktivitas bakteri di dalam anoda yang lama kelamaan dapat membentuk Biofilm pada permukaan elektroda dan semakin tinggi konsentrasi suatu larutan semakin tinggi daya hantar listriknya atau konduktivitasnya.

\section{DAFTAR PUSTAKA}

[1] Bullen RA, Arnot TC, Lakeman JB, dan Walsh FC. 2006. Biofuel Cell And Their Development. J. Biosensors and Bioelectronics 21: 2015-2045. 
[2] Keenan, CW. Kleifelter, DC dan Nood, JH. 1984. Ilmu Kimia Untuk Universitas. Edisi 6. Jilid 1. Alih Bahasa : Pudjaatmaka. Erlangga. Jakarta

[3] Kim, MH. 2009. An Analysis of Anaerobic Dual-Anode Chambered Microbial Fuel Cell (MFC) Performance. Master's Thesis, University of Tennessee.

[4] K. Murray dan Robert, dkk. 2003. Biokimia Harper. Jakarta: Penerbit Buku Kedokteran EGC.

[5] Lee, Seung Won. Jeon, Bo Young. Park, Doo Hyun. 2010. Effect Of Bacterial Cell Size On Electricity Generation In A Single-Compartmented Microbial Fuel Cell. Biotechnol Lett 32.

[6] Yoo, ES. 2000. Biological And Chemichal Mechanism Of Reductive Decolorization Od Azzo Dyes Biofilm. The Dissertation. Genehmitge, Berlin. 